\title{
PEMBERDAYAAN ANGGOTA CREDIT UNION SEBAGAI UPAYA PENGENTASAN KEMISKINAN DI KALIMANTAN BARAT
}

\author{
Sabinus Beni ${ }^{10}$ \\ Ilmu Ekonomi, Program Doktor Ilmu Ekonomi Universitas Tanjungpura \\ Jl Daya Nasional, Kel. Bansir Laut, Pontianak Tenggara, Kalimantan Barat, 78113 \\ E-mail : sabinusbeni@gmail.com
}

\begin{abstract}
ABSTRAK
Penelitian dilakukan pada Credit Union (CU) anggota Pusat Koperasi Kredit di Kalimantan Barat yaitu PUSKOPCUINA, PUSKOPDIT Bumi Borneo, PUSKOPDIT Khatulistiwa, dan PUSKOPDIT Kapuas untuk mengetahui kegiatan pemberdayaan yang telah dilakukan oleh CU terhadap anggotanya sebagai upaya untuk mengentaskan kemiskinan melalui CU. Metode penelitian merupakan menggunakan jenis penelitian kualitatif deskriptif untuk menjelaskan tentang jenis-jenis pemberdayaan anggota CU sehingga dapat menjadi rujukan bagi pengentasan kemiskinan di Indonesia khususnya Kalimantan Barat. Hasil penelitian menunjukkan bahwa terdapat berbagai kegiatan pemberdayaan yang dilakukan oleh CU dengan berbagai cara dan pendekatan penerapannya sesuai dengan kearifan lokal setempat dan tidak bertentangan dengan Anggaran Dasar dan Anggaran Rumah Tangga serta tertuang dalam Pola Kebijakan dalam rangka ikut serta mengambil peran menyejahterakan masyarakat yang menjadi anggota diantaranya melalui kegiatan pemberdayaan antara lain Pendidikan Calon Anggota, Pendidikan Dasar, Pendidikan Kredit, Pendidikan Lanjutan/Pendidikan Motivasi, Pendampingan Usaha Produktif Anggota, Pendampingan Kelompok Anggota, Iuran Solidaritas, Rapat Anggota Tahunan, Kelompok Inti/Anggota Potensial. Semua kegiatan pemberdayaan tersebut wajib diikuti oleh setiap anggota agar cita-cita kesejahteraan bersama melalui gerakan CU dapat tercapai. Pelaksanaan kegiatan pemberdayaan tersebut dilakukan secara fleksibel serta tidak memaksa namun diwajibkan, karena sebagai anggota CU wajib dan harus memiliki kesadaran untuk mengubah derajat hidup keluarga sebagaimana tujuan dan cita-cita berdirinya CU.
\end{abstract}

Kata Kunci: Credit Union, Pemberdayaan, Kemiskinan, Kesejahteraan, Pendidikan

\section{PENDAHULUAN}

Kemiskinan dan pengangguran merupakan sebuah masalah klasik yang menjadi pekerjaan rumah bagi pemerintah terutama daerah-daerah yang jauh dari pusat pemerintahan. Angka kemiskinan dan pengangguran di beberapa daerah mengalami peningkatan yakni ada 16 (enam belas) Provinsi di Indonesia pada tahun 2019 yang berada pada angka $10 \%$ (sepuluh persen) berdasarkan data dari Badan Pusat Statistik (BPS) tahun 2019. Berdasarkan data tersebut di atas, mayoritas diisi oleh Provinsi-provinsi di Indonesia Bagian Timur antara lain Nusa Tenggara Timur, Papua, dan Papua Barat dengan angka kemiskinan diatas $20 \%$ (dua puluh persen).

Berdasarkan data BPS tahun 2019, ada beberapa provinsi yang mengalami kenaikan angka kemiskinan, diantara 5 (lima) besar provinsi tersebut yang mengalami peningkatan angka kemiskinan di Wilayah Indonesia bagian Barat adalah Provinsi Kalimantan Barat, sementara selebihnya berada di wilayah Indonesia Bagian Tengah dan Timur (BPS, 2019). Berdasarkan data BPS tersebut Provinsi Kalimantan Barat menduduki peringkat 21 (dua puluh satu) secara Nasional atau dengan persentase sebanyak 7,49\% penduduk miskin atau jika dibandingkan 5 (lima) Provinsi di Pulau Kalimantan menduduki peringkat 1 (satu) yang berarti bahwa Provinsi Kalimantan Barat cukup tinggi angka penduduk miskin. Sebagai gambaran berikut angkat kemiskinan di Pulau Kalimantan: Kalimantan Selatan 4,55\%, Kalimantan Tengah 4,98\% Kalimantan Timur $5,94 \%$, Kalimantan Utara 6,63\%, dan Kalimantan Barat 7,49\%. (Adharsyah, 2019).

Kondisi di atas yang menjadi konsentrasi penulis sehingga sangat penting dilakukan penelitian tentang peranan kegiatan pemberdayaan yang dilakukan oleh Credit Union yang kita ketahui berkembang sangat pesat di Pulau Kalimantan, mengingat berbagai Credit Union (CU) tumbuh dan berkembang pesat di Kalimantan Barat serta menjadi rujukan CU-CU di seluruh Indonesia dalam pengembangan dan pemberdayaan melalui $\mathrm{CU}$, sementara angka kemiskinan meningkat cukup tinggi di Kalimantan Barat bahkan jika dibandingkan dengan Provinsi lainnya di pulau Kalimantan.

Permasalahan dalam penelitian ini adalah Sejak tahun 1976 gerakan Credit Union (CU) telah ada di Kalimantan Barat seiring berjalannya waktu dan peran Misionaris Katolik yang secara perlahan-lahan menjadi sebuah gerakan ekonomi kerakyatan masyarakat pedalaman Kalimantan Barat serta mulai berkembangan pada tahun 2000-an hingga sekarang. Kehadiran CU di Provinsi Kalimantan Barat dalam rangka sebagai upaya pengentasan kemiskinan pada bidang pendidikan, kesehatan, dan kesejahteraan sosial dengan pertumbuhan 
jumlah anggota, tabungan dan pinjaman serta meningkatnya taraf hidup masyarakat yang terlihat dari adanya kepemilikan rumah tinggal, usaha perkebunan dan pertanian, kendaraan bermotor serta tingkat pendidikan anggota keluarga hingga perguruan tinggi semakin meningkat. Adanya berbagai indikator tersebut tersebut ternyata hingga sampai saat ini tidak terlalu signifikan mengentaskan kemiskinan dan pengangguran serta pertumbuhan ekonomi. Hal tersebut terlihat dengan naiknya angka kemiskinan dan pengangguran tahun 2019 yang menempatkan Provinsi Kalimantan Barat menduduki peringkat tertinggi angka kemiskinan dan pengangguran di Pulau Kalimantan.

Solusi untuk permasalahan di atas adalah menggali lebih dalam lagi apa saja kegiatan-kegiatan pemberdayaan yang dilakukan oleh Credit Union dalam rangka pengentasan kemiskinan anggotanya sehingga dapat menjadi acuan dan diadopsi oleh pemerintah dalam mengentaskan angka kemiskinan di Indonesia, khususnya di Provinsi Kalimantan Barat.

Beberapa teori tentang pengentasan kemiskinan melalui pemberdayaan Dalam bukunya yang berjudul Community Development, Creating Community Alternatives-Vision, Analisis and Practice, definisi pemberdayaan ialah memberikan sumber daya, kesempatan, pengetahuan, dan keterampilan kepada warga untuk meningkatkan kemampuan mereka dalam menentukan masa depan mereka sendiri dan berpartisipasi pada upaya mempengaruhi kehidupan dari kelompoknya. Pengembangan masyarakat terdiri dari 4 (empat) yaitu; perspektif pluralis, Elitis, Strukturalis, Post-Strukturalis (Zubaedi, 2013). Pemberdayaan masyarakat menurut teori Actors dalam artikel berjudul "Teori Actors dalam Pemberdayaan Masyarakat" mengarah pada pendelegasian secara sosial dan moral sejumlah aspek berikut: Mendorong ketabahan Mendelegasikan wewenang sosial Mengatur kinerja Mengembangkan organisasi Menawarkan kerja sama Berkomunikasi secara efisien Mendorong inovasi Menyelesaikan masalah-masalah yang terjadi (Maani, 2011).

Peranan Credit Union untuk mengatasi permasalahan sosial ekonomi yang dihadapi oleh anggota studi kasus terhadap lima Credit Union di Yogyakarta. Hasil dari penelitian mengemukakan bahwa Credit Union berperan membantu menyelesaikan masalah sosial ekonomi yang dihadapi anggotanya melalui produk-produk serta program-program yang dilakukan (Septyarini, 2016).

Pemberdayaan melalui Koperasi Credit Union (CU) Khatulistiwa Bakti Pontianak dalam upaya pemberdayaan menunjukkan bahwa Credit Union (CU) sebagai suatu lembaga yang dalam perannya melalui pemberdayaan anggota secara tidak langsung memfasilitasi masyarakat yang bergabung menjadi anggota dalam hal pengembangan ekonomi dan sosial. Melalui kebijakan yang dikeluarkan oleh Pengurus CU Khatulistiwa Bakti serta disetujui dalam Rapat Anggota Tahunan sebagai komitmen untuk menyejahterakan anggotanya dengan mengedepankan anggotanya selaku pelaku ekonomi seiring dengan terjadinya peningkatan kesejahteraan/pendapatan serta adanya perubahan pada nilai kehidupan sosial di tengah masyarakat. Keberhasilan ini merupakan hasil kerja keras yang dilakukan oleh anggota dan berdampak pada perubahanperubahan baik dalam diri pribadinya maupun terhadap lingkungan masyarakat di sekitarnya (Barombo, Asrori, \& Donatianus, 2012).

Beberapa kajian eksploratif tentang kualitas penyelenggaraan pendidikan anggota yang dilakukan oleh manajemen CU Kridha Raharja (CUKR) Yogyakarta, mengemukakan beberapa faktor yang menghambat efektivitas penyelenggaraan pendidikan anggota. Penelitian menunjukkan bahwa sebagian besar anggota yang mengikuti pendidikan dasar merasakan adanya manfaat positif yang terjadi sebagai wadah untuk dalam cara mengelola keuangan rumah tangga serta mengubah pola pikir. Secara teknis penyelenggaraan terkait ketersediaan kapasitas yang memadai bagi fasilitator serta materi yang memenuhi standar agar dapat mengakomodir serta menjawab kebutuhan anggota yang menjadi peserta (Kusuma \& Pranatasari, 2021).

Credit Union sebagai suatu lembaga keuangan yang memberikan jasa simpan pinjam kepada anggota atau yang lebih dikenal sebagai koperasi simpan pinjam, dengan cara menghimpun dana dari anggota sebagai sumber untuk penyaluran pinjaman kepada anggota yang membutuhkan dengan tujuan produktif serta memperoleh bunga pinjaman yang relatif rendah. Hasil penelitian dapat disimpulkan bahwa peran Credit Union untuk terlibat dalam memperbaiki derajat kesejahteraan anggota sangat besar yang terlihat dari tinggi partisipasi anggota dalam kapasitasnya sebagai anggota sekaligus pemilik koperasi. Kunci dari partisipasi tersebut yakni adanya kepercayaan dari para anggota terhadap manajemen dan pengurus dalam mengelola operasional koperasi (Vuspitasari, Hapsari, \& Ewid, 2019).

Jumlah tabungan dan tunggakan kredit anggota Credit Union sangat berpengaruh terhadap kesejahteraan anggota CU Lantang Tipo, peningkatan kesejahteraan anggota setelah adanya pinjaman yang diperoleh untuk tujuan yang produktif serta ditinjau dari pengeluaran keluarga seperti konsumsi rumah tangga, anggaran pendidikan anak, peningkatan bidang kesehatan dan keperluan untuk angsuran pinjaman (Beni, 2016).

Credit Union (CU) lahir sebagai upaya masyarakat melalui tangan dingin para misionaris dalam upaya perlawanan terhadap kemiskinan yang dialami oleh masyarakat pedalaman serta wujud nyata perlawanan dari kegagalan sistem kapitalisme dan menjadi jalan tengah adanya ketegangan tarikan antara sistem dominasi negara dan sistem fundamentalisme pasar. Credit Union merupakan organisasi yang berbasis pada kumpulankumpulan orang yang ingin maju bersama berbasis pada kegiatan pemberdayaan (Beni \& Rano, 2017).

Kinerja keuangan CU dengan studi kasus pada CU Bonaventura Tempat Pelayanan Ledo berdasarkan 
laporan pertanggungjawaban dalam Rapat Anggota Tahunan Tahun Buku 2016 merujukkan pada 4 (empat) aspek secara umum yaitu likuiditas: cukup baik, rasio solvabilitas: tidak baik, dan rasio profitabilitas: cukup baik. Dengan rata-rata pencapaian target yang telah ditetapkan pada tahun sebelumnya mencapai $73,92 \%$.

Kualitas pelayanan sangat berpengaruh terhadap kepuasan anggota dalam memilih CU sebagai wadah untuk berkembang, Studi kasus pada Koperasi Simpan Pinjam (KSP) Bhakti Lestari, bahwa kualitas pelayanan yang diberikan oleh karyawan dan pengurus berpengaruh terhadap kepuasan anggota yang bergabung (Khuswati \& Relita, 2019).

Daerah pedalaman dan daerah yang jauh dari pusat pemerintahan seperti daerah perbatasan negara sebagai beranda depan cerminan suatu negara sebagai daerah pengembangan perdagangan lintas batas serta ekonomi antar Negara masih menunjukkan keprihatinan yang identik dengan daerah tertinggal baik dari segi pembangunan fisik maupun sumber daya manusia. Kondisi ini memerlukan upaya nyata yang tidak hanya bisa dilakukan oleh pemerintah agar daerah perbatasan benar-benar sebagai beranda depan negara. Berkaitan dengan kondisi tersebut langkah awal yang dilakukan adalah identifikasi kondisi daerah tertinggal sebagai dasar penentuan program pembangunan yang responsif dan sesuai dengan kondisi serta keperluan masyarakat setempat agar kegiatan pembangunan benar-benar dapat dilaksanakan dengan baik dan bermanfaat bagi masyarakat di sekitar perbatasan negara (Sutaat, 2012).

\section{RUANG LINGKUP}

Ruang lingkup dalam penelitian ini adalah untuk mengetahui apa saja jenis-jenis pemberdayaan anggota CU sebagai upaya pengentasan kemiskinan. Cakupan permasalahan penelitian ini mengemukakan jenis-jenis pemberdayaan terutama yang dilakukan oleh CU untuk mengubah mindset anggota melalui pendidikan, pelatihan, dan pendampingan agar anggota keluar dari garis kemiskinan dan dapat hidup sejahtera sebagaimana tujuan dari keberadaan CU.

Tujuan penelitian ini adalah untuk menjelaskan suatu fenomena-fenomena yang lebih mendalam untuk menjawab permasalahan penelitian yang diteliti serta memperoleh data yang sangat akurat dan dapat dipercaya (Beni, Manggu, \& Sensusiana, 2018).

\section{BAHAN DAN METODE}

Penelitian ini merupakan jenis penelitian kualitatif untuk menyelidiki, menemukan, menggambarkan serta menjelaskan temuan-temuan dari kegiatan penelitian yang dilakukan terkait pemberdayaan Credit Union dalam meningkatkan derajat hidup masyarakat yang bergabung sebagai anggota Credit Union tersebut.

Penelitian ini dibagi dalam 5 (lima) tahap untuk memudahkan peneliti dalam menggali permasalahan di lapangan serta mendeskripsikannya (Hidayat, 2012), dalam penelitian ini dilakukan kegiatan antara lain: mengungkapkan pokok permasalahan, mengungkapkan pertanyaan-pertanyaan penelitian, mengumpulkan data penelitian yang relevan di lapangan, menganalisis data dan mendeskripsikannya serta menjawab pertanyaan penelitian berdasarkan temuan lapangan.

Tahapan dari penelitian ini adalah: melakukan identifikasi permasalahan dan tujuan penelitian dengan mempelajari penelitian-penelitian terdahulu serta teoriteori yang berkaitan dengan pengentasan kemiskinan, mengajukan permohonan pengambilan data kepada 4 (empat) Pusat Koperasi Kredit (PUSKOPDIT) di Kalimantan Barat, melalukan wawancara secara daring kepada aktivis CU secara acak dan mendalam, pengambilan dokumentasi pendukung melalui website CU Primer dan Puskopdit terkait kegiatan pemberdayaan, data yang telah dikumpulkan dianalisis serta dijelaskan sesuai tujuan penelitian.

\section{PEMBAHASAN}

Beberapa penelitian terdahulu yang dilakukan terhadap $\mathrm{CU}$ belum menggambarkan tentang pemberdayaan apa saja yang terdapat di CU secara keseluruhan, karena penelitian-penelitian tersebut biasanya mengambil studi kasus salah satu CU. Dalam penelitian ini, kegiatan pemberdayaan yang ditemukan atau yang dijelaskan merupakan pemberdayaan dari semua CU di Kalimantan Barat melalui 4 (empat) Pusat Koperasi Kredit (PUSKOPDIT).

Berdasarkan temuan di lapangan terhadap beberapa CU di Kalimantan Barat, ditemukan bahwa kegiatan pemberdayaan dalam credit union sebagai upaya dalam pengentasan kemiskinan sebanyak 9 (sembilan), yaitu: pendidikan calon anggota, pendidikan dasar, pendidikan kredit, pendidikan lanjutan/motivasi, pendampingan usaha produktif anggota, pendampingan kelompok anggota, iuran solidaritas, rapat anggota tahunan, kelompok inti/anggota potensial/kolektor. Jenis kegiatan yang dilakukan sesuai dengan ketentuan dan pola kebijakan masing-masing CU (Beni, 2017).

Pendidikan merupakan pilar terpenting dalam kegiatan pemberdayaan anggota Credit Union. Idealnya setiap masyarakat yang ingin bergabung menjadi anggota CU terlebih dahulu mengikuti Pendidikan Calon Anggota (Diklat Calon Anggota/DCA) yang bertujuan memperkenalkan AD/ART CU tersebut kepada pada calon anggota. Setelah mengikuti kegiatan ini, calon anggota yang dinyatakan lulus dapat mendaftarkan diri sebagai anggota $\mathrm{CU}$ dan mendaftarkan diri sebagai peserta Pendidikan Dasar. Di berbagai CU, pendidikan dasar berbeda-beda, ada yang pelaksanaannya lebih dari 1 (satu) kali, tergantung pola kebijakan CU tersebut.

Sesuai dengan pilar Credit Union yaitu: Pendidikan, Swadaya, Solidaritas, Inovasi, dan Persatuan. Pendidikan Dasar merupakan pengetahuan dasar seorang anggota CU untuk dapat maju bersama meraih kesejahteraan melalui pemberdayaan yang dilakukan oleh CU, sehingga dalam CU dikenal dengan istilah "Saya Susah Kamu Bantu, Kamu Susah Saya Bantu”. Dalam 
praktiknya, istilah tersebut ditanamkan kepada seluruh anggota pada saat mengikuti pendidikan dasar. Implementasi dari istilah tersebut diwujudkan melalui keaktifan anggota menabung secara rutin setiap bulan melalui setoran Simpanan Wajib, Simpanan Sukarela, dan Simpanan Non Saham serta membayar pinjaman setiap bulan sesuai tanggal jatuh tempo tepat angsuran dan tepat waktu ditunjukkan pada Gambar 1 .

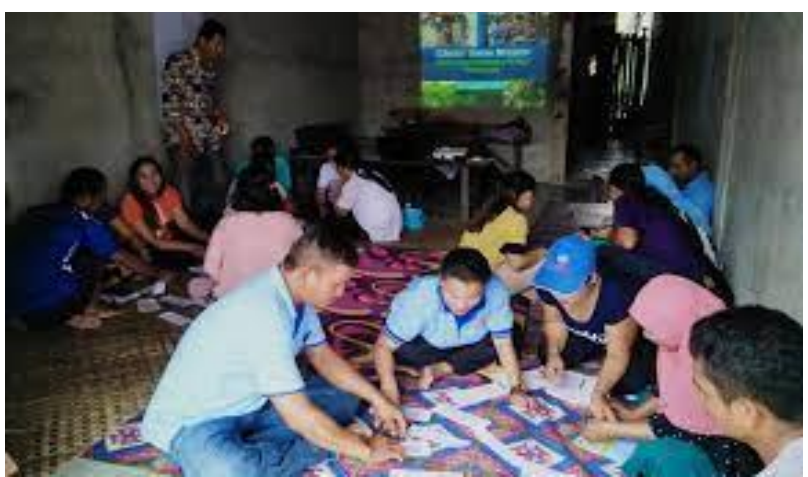

Gambar 1. Kegiatan Pendidikan Dasar CU

Ada 5 (kima) Pilar CU serta penjelasannya dapat dilihat sebagai berikut:

1. Pendidikan

Credit Union diawali melalui kegiatan Pendidikan, berkembang melalui Pendidikan, dikontrol melalui Pendidikan, serta bergantung pada Pendidikan.

2. Swadaya

Credit Union berasal dari anggota (nasabah), dikelola oleh anggota (manajemen, pengurus, dan pengawas) dan untuk anggota (nasabah, (manajemen, pengurus, dan pengawas)

3. Solidaritas

Semua anggota Credit Union harus mengedepankan nilai-nilai kebersamaan dengan Motto: "Anda susah Saya bantu, Saya susah Anda bantu”.

4. Inovasi

Inovasi merupakan tuntutan yang harus dilakukan sesuai perkembangan zaman agar dapat menyesuaikan diri serta terus berkelanjutan.

5. Persatuan

Kerja sama antar Credit Union akan memperkokoh gerakan Credit Union serta memperkuat sosial ekonomi semua anggota Credit Union dan tidak menganggap credit Union lainnya sebagai kompetitor yang harus dikalahkan.

Dalam kegiatan pendidikan ini, dijelaskan pula berbagai hal yang berkaitan dengan $\mathrm{CU}$, biasanya dengan berbagai materi yang diajarkan kepada para anggota baru, yaitu: Dasar-dasar Credit Union, Analisis Sosial, Pembangunan Manusia, Pengaturan Keuangan Keluarga, Prospek dan Produk Simpanan/Tabungan, Perkreditan, Perlindungan, Bantuan, dan Promosi. Melalui kegiatan ini, diharapkan anggota baru dapat menyesuaikan diri dengan ketentuan yang ada di CU serta dapat segera mengimplementasikannya dalam kehidupan keluarga masing-masing.

Program pendidikan yang diselenggarakan oleh Credit Union bertujuan untuk meningkatkan kapasitas dari setiap anggota. Lingkup peningkatan kapasitas yang meliputi berbagai aspek antara lain mentalitas dan spiritualitas; pengetahuan dan wawasan; keterampilan dan keahlian. Anggota yang telah mengikuti serangkaian pendidikan secara tidak langsung akan menggerakkan mereka untuk dapat menyimpan uang dan mengakses pinjam untuk meningkatkan produktivitas dan berbagai manfaat yang bisa didapat dari CU.

Pendidikan Kredit dilakukan oleh CU kepada para anggota yang akan melakukan pinjaman baik itu Pinjaman menambah simpanan/Kapitalisasi, Pinjaman Produktif, Pinjaman Konsumtif maupun Pinjaman lainnya yang bertujuan untuk mengatasi masalah yang dihadapi oleh anggota yang akan meminjam. Pendidikan Kredit wajib dan sangat penting dilakukan sebagai bagian dari kegiatan pemberdayaan, Setiap anggota yang akan meminjam harus mengikuti tahapan ini, agar pinjaman yang didapatkan dengan berbagai tujuan tidak membuat anggota jatuh kedalam jurang kemiskinan dan terlilit hutang.

Beberapa CU, biasanya menerapkan pendidikan ini ada yang secara massal kepada semua pemohon kredit dalam bulan berjalan, tetapi ada juga yang dilakukan secara individu untuk menjaga kerahasiaan infomasi dan keluhan anggota yang diatasi melalui kredit. Di sini akan dijelaskan hak dan kewajiban anggota sebagai peminjam serta hak dan kewajiban CU sebagai pemberi pinjaman. serta dijelaskan berbagai kemungkinan maupun pertimbangan jenis pinjaman yang akan diambil oleh anggota agar manfaat dari kredit benar-benar membebaskan anggota dari masalah dan mengangkat harkat dan martabatnya sebagai manusia yang lahir sebagai seorang yang bahagia dan sejahtera sesuai visi dan misi CU.

Pendidikan lanjutan dilakukan oleh setiap CU kepada para anggota yang biasanya sudah ada tanda-tanda tidak produktif lagi sebagai anggota $\mathrm{CU}$, hal ini ditandai dengan jarangnya anggota tersebut menabung atau terjadinya kredit lalai bagi anggota yang telah menerima pinjaman.

Pendidikan ini juga dilakukan kepada para anggota yang aktif dalam menjalankan perannya sebagai anggota CU, untuk menyampaikan informasi-informasi terkini yang berkaitan dengan kebijakan $\mathrm{CU}$ yang belum diketahui oleh anggota karena sesuai dengan perubahan pola kebijakan dan perkembangan zaman. Di dalam pendidikan ini, menitikberatkan kepada para peserta yang hadir untuk terus menerus memajukan CU dengan menabung rutin setiap bulan serta membayar pinjaman sesuai dengan perjanjian. Harapannya, setelah kegiatan ini para anggota termotivasi untuk terus aktif ber-CU demi mencapai kesejahteraan bersama.

Pendampingan usaha produktif anggota adalah sebuah layanan pendampingan yang disediakan oleh $\mathrm{CU}$ 
untuk terus memberdayakan anggota yang telah memiliki usaha produktif, namun masih memerlukan pendampingan agar usaha dapat berjalan dan berkembangan dengan baik. Pendampingan ini sama seperti kegiatan pendidikan sebelumnya tergantung dari masing-masing kebijakan $\mathrm{CU}$, rata-rata tanpa dipungut biaya. Hasil dari pendampingan ini juga biasanya dipasarkan melalui jaringan yang dimiliki oleh CU, baik melalui koperasi konsumsi maupun melalui unit usaha anggota lainnya yang bertujuan membantu sesama.

Pendampingan Kelompok Anggota biasanya dilakukan oleh CU terhadap anggota yang membentuk sebuah komunitas ataupun kelompok usaha bersama (KUBE). Dalam kegiatan ini, diimplementasikan antara teori yang dimiliki oleh aktivis/staf CU yang telah ditunjuk dan dipercaya untuk mendampingi kelompok anggota agar usaha dapat berkembangan dan mendapatkan hasil yang maksimal. Hasil kegiatan pendampingan kelompok anggota yang dipasarkan pada saat kegiatan Rapat Anggota Tahunan (RAT) dilakukan pada tempat yang telah disediakan oleh panitia ditunjukkan pada Gambar 2.

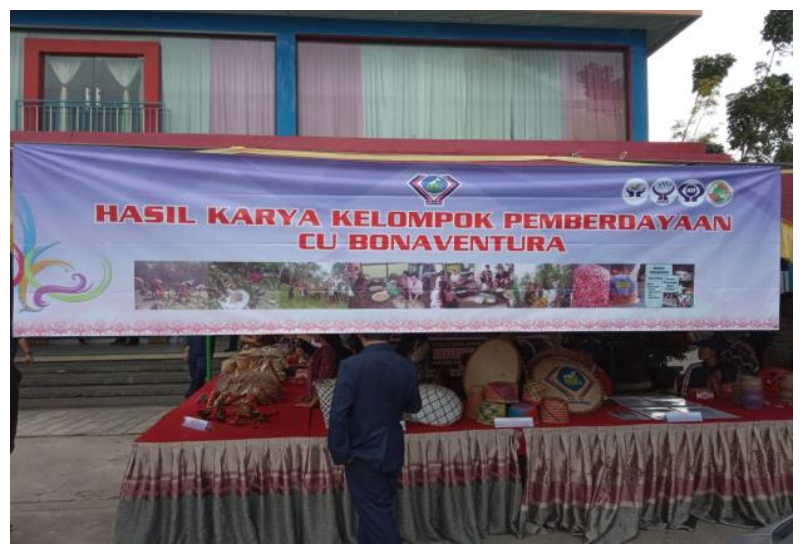

Gambar 2. Hasil Karya Kelompok Anggota CU

Pemberdayaan ini dilakukan sesuai dengan kebutuhan setiap kelompok, ada yang bergerak di bidang pertanian, perkebunan, perdagangan serta usaha lainnya sesuai dengan kesepakatan bersama dan disetujui oleh CU untuk dilakukan pendampingan.

Iuran solidaritas merupakan salah satu aksi nyata kegiatan pemberdayaan dalam mencapai kesejahteraan bersama. Rata-rata iuran solidaritas ini bervariasi antara satu $\mathrm{Cu}$ dengan $\mathrm{CU}$ lainnya, tetapi jenis-jenisnya hampir sama yaitu Solidaritas Kesehatan (SOLKES) untuk membantu anggota CU yang mengalami sakit dan berobat di layanan kesehatan yang diakui oleh pemerintah dengan iuran dan besarnya klaim yang diterima sesuai pola kebijakan, Solidaritas Duka Cita untuk membantu anggota CU yang terkena musibah duka cita, dan Bantuan Sosial diberikan kepada anggota CU yang mengalami musibah baik karena bencana alam maupun karena musibah lainnya. Iuran solidaritas ini merupakan bentuk kepedulian terhadap sesama yang menderita dan sebagai rasa kepedulian anggota CU terhadap anggota yang lainnya agar segera bangkit dari masalah yang dihadapinya.

Dalam Rapat Anggota Tahunan (RAT), anggota memegang peranan yang sangat penting, selain kewenangan yang diamanatkan kepada para Pengurus dan Pengawas serta Manajemen yang dipercaya dalam mengelola CU. Dalam kegiatan RAT ini tidak hanya dilakukan untuk memaparkan laporan pertanggungjawaban (LPJ) CU tetapi juga sebagai wadah untuk bertukar pikiran, informasi serta sebagai sarana promosi bagi usaha-usaha anggota dan sebagai ajang silaturahmi kepada sesama untuk saling mendukung dalam setiap karya sebagai anggota CU. Kegiatan RAT CU di Kalimantan Barat selalu diikuti secara antusias oleh anggota yang dibuktikan dengan ramainya peserta yang hadir, baik yang diundang resmi menjadi perwakilan maupun yang datang tanpa hak berbicara untuk menyaksikan RAT ditunjukkan pada Gambar 3.

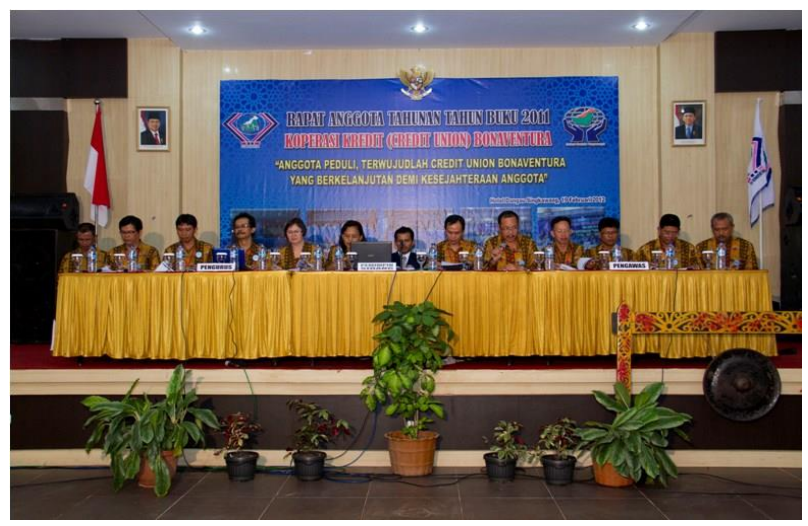

Gambar 3. Rapat Anggota Tahunan CU

Kelompok Inti/Anggota Potensial merupakan salah satu Roh dari CU, Pemberdayaan-pemberdayaan yang dilakukan oleh mereka tidak hanya sekadar menerima titipan setoran tabungan dan pinjaman dari para anggota, tetapi juga sebagai orang yang terdepan dalam memberikan motivasi kepada para anggota di wilayah tempat tinggalnya agar terus menerus menjadi anggota CU yang aktif dan produktif.

\section{KESIMPULAN}

Dalam penelitian ini dapat disimpulkan bahwa, dalam mengangkat harkat dan martabat masyarakat yang menjadi anggota Credit Union, dilakukan melalui kegiatan pemberdayaan terus menerus yakni: Pendidikan Calon Anggota, Pendidikan Dasar, Pendidikan Kredit, Pendidikan Lanjutan, Pendampingan Usaha Produktif Anggota, Pendampingan Kelompok Anggota, Iuran Solidaritas, Rapat Anggota Tahunan, Kelompok Inti/Anggota Potensial maupun kolektor. Dari semua kegiatan pemberdayaan yang dilakukan serta dengan perkembangan CU yang sangat bagus di Kalimantan Barat ternyata belum membawa dampak yang signifikan dalam mengentaskan angka kemiskinan yang tergambar dari tingginya angka kemiskinan di Kalimantan Barat 
tahun 2019 dari seluruh Provinsi yang ada di Pulau Kalimantan. Hal ini disebabkan karena masih banyaknya masyarakat miskin yang belum bergabung menjadi anggota CU serta masih adanya mindset masyarakat di luar Suku Dayak dan Agama Kristiani yang menganggap bahwa CU hanya untuk suku dan agama tersebut serta banyak masyarakat yang belum mengenal kegiatan pemberdayaan CU secara dalam yang membuatnya tidak bergabung dan menjadi anggota.

\section{SARAN}

Berdasarkan hasil penelitian yang dilakukan, penulis menyarankan untuk dapat dilakukan penelitian yang lebih mendalam lagi tentang pemberdayaan anggota Credit Union dalam mengentaskan kemiskinan dalam skala yang lebih luas, yaitu skala Provinsi. Agar data dan hasil penelitian dapat digunakan sebagai media untuk dijadikan pedoman dalam mengentaskan kemiskinan oleh pemerintah, baik pemerintah daerah maupun pemerintah pusat.

\section{DAFTAR PUSTAKA}

Adharsyah, T. (2019). Miris, Tingkat Kemiskinan di 6 Provinsi Ini Meningkat. Retrieved from https://www.cnbcindonesia.com/news/201907151642 11-4-85070/miris-tingkat-kemiskinan-di-6-provinsiini-meningkat

Barombo, A., Asrori, \& Donatianus. (2012). Pemberdayaan Masyarakat Melalui Koperasi Credit Union (CU) Studi Pada CU. Khatulistiwa Bakti Pontianak. Universitas Tanjungpura.

Beni, S. (2016). Pengaruh Simpanan dan Tunggakan Kredit Terhadap Kesejahteraan Anggota Credit Union (Studi Kasus Koperasi Kredit CU Lantang Tipo). Prosiding Seminar Nasional FE Universitas Terbuka, VIII(Challange and Strategy Faculty EconomicsAnd BusinessIn Digital Era), 333-339. Retrieved from repository.ut.ac.id

Beni, S. (2017). Pembangunan Manusia Melalui Pendidikan Dasar Credit Union. (Herulono, Ed.). Jakarta: Mer-C Publishing.

Beni, S., Manggu, B., \& Sensusiana. (2018). Modal Sosial Sebagai Suatu Aspek Dalam Rangka Pemberdayaan Masyarakat. JURKAMI, 3(1), 8-24. Retrieved from http://jurnal.stkippersada.ac.id/jurnal/index.php/JPE/a rticle/view/341

Beni, S., \& Rano, G. (2017). Credit Union Sebagai Penggerak Ekonomi Masyarakat Dayak Kalimantan Barat. Prosiding International Congress I Dayak Culture 1, 1(1), 168-177.

BPS. (2019). Kabupaten Bengkayang Dalam Angka 2019. (BPS, Ed.) (2019th ed.). Bengkayang: BPS
Kabupaten Bengkayang.

Hidayat, A. (2012). Penelitian Kualitatif (Metode): Penjelasan Lengkap. Retrieved from https://www.statistikian.com/2012/10/penelitiankualitatif.html

Khuswati, E., \& Relita, D. T. (2019). Pengaruh Kualitas Pelayanan Koperasi Terhadap Kepuasan Anggota Koperasi Simpan Pinjam (KSP) Bhakti Lestari Kecamatan Sungai Tebelian. JURKAMI: Jurnal Pendidikan Ekonomi, 4(2), 89-98.

Kusuma, S. E., \& Pranatasari, F. D. (2021). Kajian Eksploratif Kualitas Penyelenggaraan Pendidikan Lembaga Keuangan Berbasis Pemberdayaan Masyarakat: Studi Kasus Credit Union Kridha Rahardja. Management and Sustainable Development Journal, 3(1), 1-21.

Maani, K. D. (2011). Teori ACTORS dalam Pemberdayaan Masyarakat. Demokrasi, X(1), 53-66. Retrieved from https://media.neliti.com/media/publications/242140teori-actors-dalam-pemberdayaan-masyarakac3d6590.pdf

Septyarini, E. (2016). Peran Credit Union Dalam Menjawab Permasalahan Sosial Ekonomi Yang Dihadapi Oleh Anggotastudi Kasus Pada Lima Credit Union Di Daerah Istimewa Yogyakarta. Universitas Sanata Dharma.

Sutaat. (2012). Pemberdayaan Masyarakat Daerah Perbatasan Antar Negara: Studi Masalah, Kebutuhan dan Sumber Daya Sosial Desa Jagoi, Kecamatan Jagoi Babang-Kabupaten Bengkayang, Kalimantan Barat. Sosiokonsepsia, 17(1), 8-17.

Vuspitasari, B. K., Hapsari, V. R., \& Ewid, A. (2019). Partisipasi Anggota Dalam Mengembangkan Credit Union. Jurnal Bisnis Ekonomi Dan Entrepreneurship, 1(2), 8-15. Retrieved from https://journal.shantibhuana.ac.id/index.php/bee/articl e/view/88/43

Zubaedi. (2013). Pengembangan Masyarakat Wacana dan Praktek. Jakarta: Pustaka Kencana Prenada Media Group.

\section{UCAPAN TERIMA KASIH}

Terima kasih penulis sampaikan kepada pihak-pihak yang telah berkontribusi dalam penelitian ini, terutama pihak Yayasan Santo Yohanes Salib, Program Doktor Ilmu Ekonomi Universitas Tanjungpura Pontianak, Pengurus dan Manajemen Credit Union di Kalimantan Barat serta pihak-pihak yang tidak dapat penulis sebutkan satu per satu. 